\title{
UTILIZAÇÃO DE ENSAIO COMETA PARA DETECTAR EFEITO GENOTÓXICO DO MMS EM CÉLULAS DE BIOMPHALARIA GLABRATA
}

\author{
Dewson R. Pereira ${ }^{1 *}$, Maíra de V. Lima ${ }^{1}$, Willams N. de Siqueira ${ }^{1}$, Gabrielly Christynne N. Sales ${ }^{1}$, Hianna Arely M. F. \\ Silva ${ }^{1}$, José Luiz F. Sá1, Francisco F. Amâncio ${ }^{1}$, Ana Maria Mendonça de A. Melo ${ }^{1}$ \\ ${ }^{1}$ Departamento de Biofísica e Radiobiologia, Laboratório de Radiobiologia, UFPE \\ *dewson.rocha@gmail.com
}

\section{INTRODUÇÃO}

Devido as diversas atividades humanas, milhares de substâncias nocivas são liberadas diariamente no ambiente podendo causar impactos danosos aos organismos vivos ali presentes (AMORIM et al., 2003). O meio aquático é um dos principais locais para descartes de resíduos industriais, esgotos domésticos e outros. Estas substâncias podem acarretar prejuízos para a sobrevivência das espécies que vivem neste ambiente (CAJARAVILLE et al., 2000). As consequências são alterações fisiológicas, comportamentais, malformações, mudanças nas taxas de crescimento, reprodução ou até mesmo a morte de toda a comunidade, afetando a estrutura do ecossistema (RESH, DAVID \& VH, 1993; CLEMENTS, 2000). As malformações causadas por alterações da molécula de DNA, podem ser um risco também para a saúde humana, por ser repassada por meio da cadeia alimentar (JHA, 1998). Como consequência pode ocorrer doenças congênitas, doenças genéticas (mutagênese) e degenerativas, envelhecimento celular, câncer, entre outras (ERDTMANN, 2003).

Para o biomonitoramento e identificação do grau de dano sofrido nos seres vivos de um ecossistema, se faz necessário, portanto, uma técnica que avalie os parâmetros relacionados com os danos nestes organismos. O Ensaio Cometa (teste de células individualizadas em gel de agarose) é um método desenvolvido para detectar quebras no DNA de forma preventiva (pré-mutagê nese) (KAMMANN et al., 2001). As células, avaliadas por esta té cnica, que possuírem elevado grau de dano no DNA apresentam uma forma semelhante a de um cometa, pois ocorre aumento na migração de DNA cromossomal do núcleo (SPEIT \& HARTMANN, 1999). O Ensaio Cometa é utilizado em diversas áreas de conhecimento, incluindo biomonitoramento ambiental, genética toxicológica, radiação biológica, processos de reparo de DNA e ecotoxicologia genética (GONTIJO \& TICE, 2003).

O molusco Biomphalaria glabrata (B. glabrata), considerado um biomonitor ambiental (CLAXTON, HOUK \& HOUGHES, 1998) foi utilizado recentemente para avaliar alterações ao DNA através do ensaio cometa (GRAZEFFE et al., 2008). A hemolinfa deste animal contem hemócitos (células de defesa) que irão estar em contato direto com os contaminantes. Portanto, este tecido é apropriado para o teste do cometa (VILLELA et al., 2006). Neste estudo, moluscos B. glabrata foram expostos à substância genotóxica metanosulfonato de metila (MMS), com a finalidade de observar dano à molécula de DNA, por meio do ensaio cometa.

\section{MATERIAIS E MÉTODOS}

Animais
Foram utilizados moluscos adultos da espécie $B$. glabrata pigmentados, apresentando 10-14 mm de diâmetro, oriundos do Moluscário do Laboratório de Radiobiologia localizado no Departamento de Biofísica e Radiobiologia da UFPE. Os animais foram mantidos em tanques plásticos de aproximadamente $20 \mathrm{~L}$ contendo água filtrada e declorada (ph 7,0 e temperatura de $25 \pm$ $2^{\circ} \mathrm{C}$ ) e alfaces orgânicos frescos (alimentação diária).

\section{Exposição ao MMS}

Foram utilizados 5 animais para o grupo exposto ao $\mathrm{MMS}(0,3 \mathrm{mM})$ (Acros organics) e para o grupo controle (água filtrada e declorada). A exposição dos animais selecionados foi de $24 \mathrm{~h}$.

\section{Ensaio cometa}

0 ensaio alcalino do Cometa foi feito como descrito por Singh e col. (1988), com modificações. Para cada animal duas lâminas de microscópio foram cobertas com agarose de ponto de fusão normal 1,5\% (Sigma-aldrich) dissolvida em PBS (livre de $\mathrm{Ca}^{2+} \mathrm{e} \mathrm{Mg}^{2+}$ ). Foi coletado $100 \mu \mathrm{L}$ de hemolinfa de cada animal, através de estimulo sucessivo da região podal, que culmina na liberação de hemolinfa pelo animal. Este volume de hemolinfa foi homogeneizado em 100 $\mu \mathrm{L}$ de agarose de baixo ponto de fusão, e colocado sobre a lâmina coberta com a agarose de ponto de fusão normal. Após solidificaçã o a $4^{\circ} \mathrm{C}$ (5-10 min), as lâminas foram incubadas em solução de lise ( $\mathrm{NaCl}$ 2,5 M, EDTA $100 \mathrm{mM}$, Tris $10 \mathrm{mM}$, Triton-X 100 1\% e DMSO 10 $\%$, pH 10,0) por $12 \mathrm{~h}$ a $4{ }^{\circ} \mathrm{C}$. Após lise, as lâminas foram colocadas em uma cuba $(10 \mathrm{~cm} \times 28 \mathrm{~cm})$ de eletroforese horizontal e imersas em tampão alcalino, pH 13,0 (EDTA $1 \mathrm{mM}$ e NaOH $300 \mathrm{mM}$ ) por 20 min e submetidas a eletroforese $(0,74 \mathrm{~V} / \mathrm{cm}, 150 \mathrm{~mA})$ por $20 \mathrm{~min}$ a $4^{\circ} \mathrm{C}$. As lâminas foram então neutralizadas com tampão Tris $0,4 \mathrm{M}$, pH 7,5 por $15 \mathrm{~min}$, fixadas com álcool absoluto por $10 \mathrm{~min} e$ coradas com SYBR safe (Invitrogen). Foram analisadas 100 células por animal em microscópio de fluorescência (Nikon H550L) em aumento de 400x, com um filtro de excitação de $450-490 \mathrm{~nm}$, filtro de emissão de 500-550 nm e um filtro de barreira de $495 \mathrm{~nm}$. A aná lise visual dos danos nos hemócitos foi realizada de acordo com Jaloszynski e col. (1997), que consistiu na classificação dos cometas em categorias ( 0 a 3 ). Cada uma dessas categorias representa, de forma crescente, a extensão do dano ao DNA. Por exemplo, na categoria 0 os cometas não apresentam cauda, na categoria 3 os cometas apresentam cabeça pequena e cauda longa contendo a maior parte do conteúdo de DNA (dano máximo).

\section{RESULTADOS E DISCUSSÃO}


O efeito genotóxico do MMS foi avaliado sobre hemócitos de $B$. glabrata através do Ensaio Cometa. No ensaio foi observada a presença de cauda e diminuição da cabeça dos nucleóides do grupo exposto ao MMS em comparação ao grupo controle (Figura 1). A aná lise visual dos cometas demonstrou que $90 \%$ dos nucleóides do grupo exposto ao MMS 0,3 $\mathrm{mM}$ apresentaram dano ao DNA entre as categorias 2 e 3 , indicando migração do DNA cromossomal danificado comparado ao grupo controle. Portanto, a concentração de 0,3 mM de MMS foi capaz de induzir dano ao material genético do B. glabrata.

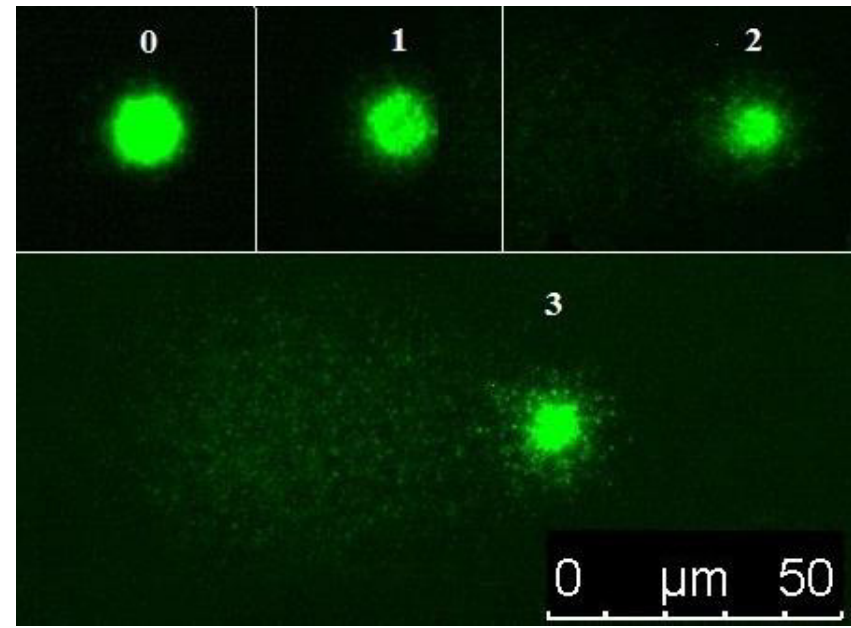

Figura 1. Imagens de cometas, a partir de hemócitos expostos ao MMS de Biomphalaria glabrata, corados com SYBR safe. Categoria zero (0) representa a ausência de dano gené tico, e as categoria de 1-3 indicam dano ao DNA de forma crescente. (Fonte: Autor).

Estudos recentes utilizaram o MMS em ensaio cometa com diferentes sistemas biológicos, desde células de mamíferos (COLLIN, DUšINSKÁ \& HORSKÁ, 2001), peixes (LEMOS et al., 2005) e invertebrados (RIGONATO, MANTOVANI \& JORDÃO, 2005; CHEUNG, DEPLEDGE \& JHA, 2006). Este agente genotóxico demonstrou sensibilidade ao ensaio do cometa com B. glabrata e deu uma resposta positiva na concentração utilizada. 0 MMS é um agente alquilante que atua sobre os centros nucleofílicos do DNA formando monoadutos (tipo de ligação química), por meio de uma reação de substituição (JENKINS et al., 2005). Diferentes respostas celulares são ocasionadas pela formação de monoadutos, como: parada na replicação, inibição da transcrição, parada no ciclo celular, reparo do DNA e morte celular (WANG \& LIPPARD, 2005).

\section{CONCLUSÕES}

A utilização do Ensaio Cometa com B. glabrata possibilita a obtenç ão de informações a nível molecular, o que permite estudar a ação de agentes físicos ou químicos de forma sensível e preventiva. Portanto, os testes de biomonitoramento ambiental ganham mais uma ferramenta para controle da qualidade da biodiversidade.

\section{REFERÊNCIAS}

AMORIM, L. C. A. Os biomarcadores e sua aplicação na avaliação da exposição aos agentes químicos ambientais. Revista Brasileira de Epidemiologia, v. 6, p. 158-170. 2003.

BRENDLER-SCHWAAB, S.; HARTMANN, A.; PFUHLER, S. \& SPEIT, G. The in vivo comet assay: use and status in genotoxicity testing. Mutagenesis, v. 20, n. 4, p 245-254, 2005.

BURLINSON, B.; TICE, R. R.; SPEIT, G.; AGURELL, E.; BRENDLERSCHWAAB, S. Y.; COLLINS, A. R.; ... \& SASAKI, Y. F. Fourth International Workgroup on Genotoxicity testing: results of the in vivo Comet assay workgroup. Mutation Research/ Genetic Toxicology and Environmental Mutagenesis, v. 627, n. 1, p. 3135, 2007.
CAJARAVILLE, M. P.; BeBIANNO, J. M.; BLASCO, J.; PORTE, C.; SARASQUETE, C.; VIARENGO, A. The use of biomarkers to assess the impact of pollution in coastal environments of the Iberian Peninsula: a practical approach. Science of the Total Environment, v. 247, n. 2, p. 295-311, 2000.

CHEUNG, V. V.; DEPLEDGE, M. H.; JHA, A. N. An evaluation of the relative sensitivity of two marine bivalve mollusc species using the Comet assay. Marine Environment Research, v. 62, p. S301-S305, 2006.

CLAXTON, L. D.; HOUK, V. S.; HUGHES, T. J. Genotoxicity of industrial wastes and effluents, Mutation Research, v. 410, n. 3, p. 237-243, 1998.

CLEMENTS, W. H. Integrating effects of contaminats across levels of biological organization. Journal Ecosystem Stress and Research, v. 7, n. 2, p. 113-116, 2000.

COLLINS, A. R.; Al-GUO, M. \& DUTHIE, S. J. The kinetics of repair of oxidative DNA damage (strand breaks and oxidized pyrimidines) in human cells. Mutation Research/DNA Repair, v. 336, n. 1, p. 69-77, 1995.

COLLINS, A. R.; DUŠINSKÁ, M. \& HORSKÁ, A. Detection of alkylation damage in human lymphocyte DNA with the comet assay. 2001.

ERDTMANN, B. A genotoxicidade nossa de todos os dias. In: Silva, J.; Erdtmann, B.; Henriques, J. A. P. Genética Toxicológica. Porto Alegre: Alcance. 2003.

LEMOS, N. G.; DIAS, A. L.; SILVA-SOUZA, A. T. \& MANTOVANI, M. S. Evaluation of environmental waters using the comet assay in Tilapia rendalli. Environmental Toxicology and Pharmacology, v. 19, n. 2, p. 197-201, 2005.

GONTIJO, A. M. M. C. \& TICE, R. Teste do cometa para a detecção de dano no DNA e reparo em células individualizadas. Mutagênese Ambiental. Canoas: Ulbra. p. 173-200, 2003.

GRAZEFFE, V. S.; DE FREITAS TALLARICO, L.; DE SA PINHEIRO, A.; KAWANO, T.; SUZUKI, M. F.; OKAZAKI, K.; ... \& NAKANO, E. Establishment of the comet assay in the freshwater snail Biomphalariaglabrata (Say, 1818). Mutation Research/ Genetic Toxicology and Environmental Mutagenesis, v. 654, n. 1, p. 5863, 2008.

JAŁOSZYŃSKI, P.; KUJAWSKI, M.; CZUB-ŚWIERCZEK, M.; MARKOWSKA, J. \& SZYFTER, K. Bleomycin-induced DNA damage and its removal in lymphocytes of breast cancer patients studied by comet assay. Mutation Research/ DNA Repair, v. 385, n. 3, p. 223233, 1997.

JENKINS, G. J. S.; DOAK, S. H.; JOHNSON, G. E.; QUICK, E.; WATERS, E. M. \& PARRY, J. M. Do dose response thresholds exist for genotoxic alkylating agents? Mutagenesis, v. 20, n. 6, p. 389398, 2005.

JHA, A.N. Use of aquatic invertebrates in genotoxicological studies, Mutat. Res, v. 399, n. 1, p. 1-2, 1998.

KAMMANN, U.; BUNKE, M.; STEINHART, H. A permanent fish cell line (EPC) for genotoxicity testing of marine sediments with the comet assay. Mutation Research, Amsterdam. v. 498, p. 61-77, 2001.

RIGONATO, J.; MANTOVANI, M. S.; JORDÃO, B. Q. Comet assay comparison of different Corbicula fluminea (Mollusca) tissues for the detection of genotoxicity. Genetics and Molecular Biology, v. 28, n. 3, p. 464-468, 2005.

RESH, V. H. R.; DAVID, M.; VH, Resh. Freshwater biomonitoring and benthic macroinvertebrates. 1993.

SABATIER, L.; LEBEAU, J.; DUTRILLAUX, B. Radiation-induced carcinogenesis: individual sensitivity and genomic instability. Radiation and Environmental Biophysics, v. 34, n.4, p.293-232, 1995.

SINGH,N.P. M.T. MCCOY, R.R. TICE, E.L. SCHNEIDER, A simple technique for quantitation of low levels of DNA damage in individual cells, Experimental cell research. v. 175, n. 1, p. 184191, 1988. 
SPEIT, G.; HARTMANN, A. The Comet Assay (Single-Cell Gel Test) a sensitive genotoxicity test for the detection of DNA damage and repair. DNA Repair Protocols: Eukaryotic Systems, v. 113, p. 203 212, 1999.

TICE, R. R., AGURELL, E., ANDERSON, D., BURLINSON, B., HARTMANN, A., KOBAYASHI, H., ...\& SASAKI, Y. F. Single cell gel/comet assay: guidelines for in vitro and in vivo genetic toxicology testing. Environmental and molecular mutagenesis, v. 35, n. 3, p. 206-221, 2000.

VILLELA, I. V.; OLIVEIRA, I. M.; SILVA, J.; HENRIQUES, J. A. P. DNA damage and repair in haemolymph cells of golden mussel (Limnoperna fortunei) exposed to environmental contaminants; Mutation Research, v. 605, p. 78-86, 2006.

WANG, D. \& LIPPARD, S. J. Cellular processing of platinum anticancer drugs. Nature reviews Drug discovery, v. 4, n. 4, p. 307-320, 2005. 